\title{
Ultrasonography features of abdominal perimuscular connective tissue in elite and amateur basketball players: an observational study
}

\author{
Carlos Romero Morales ${ }^{1}$ \\ Jaime Almazán Polo² \\ David Rodríguez Sanz $z^{1,3}$ \\ Daniel López López ${ }^{2}$ \\ Sergio Vázquez González 1,4 \\ José Luis Arias Buría ${ }^{5}$ \\ (iD) César Calvo Lobo ${ }^{6}$
}

\begin{abstract}
1. Faculty of Sport Sciences, Universidad Europea de Madrid, Villaviciosa de Odón, Madrid, Spain. 2. Department of Health Sciences; Research, Health and Podiatry Unit. Faculty of Nursing and Podiatry, Universidade da Coruña, Ferrol, Spain. 3. Facultad de Enfermería, Fisioterapia y Podología. Universidad Complutense de Madrid, Madrid, Spain. 4. Premiummadrid Global Health Care, Madrid, Spain. 5. Department of Physical Therapy, Occupational Therapy, Physical Medicine and Rehabilitation, Universidad Rey Juan Carlos, Alcorcón, Madrid, Spain 6. Nursing and Physical Therapy Department, Faculty of Health Sciences, Universidad de León, Ponferrada, Spain.
\end{abstract}

http://dx.doi.org/10.1590/1806-9282.64.10.936

\begin{abstract}
SUMMARY
The purpose of this study was to assess and compare with rehabilitative ultrasound imaging (RUSI) the perimuscular connective tissue (PMCT) and interrecti distance (IRD) between elite and amateur basketball players. A sample of 22 healthy basketball players was included and divided into two groups: elite basketball players from Spanish 1st division $(n=11)$ and amateur basketball players from an entertainment Spanish division $(n=11)$. Ultrasound images of the external oblique $(E O)$, internal oblique $(I O)$, transversus abdominis $(\operatorname{Tr} A b)$, rectus anterior $(R A)$ and IRD PMCT were measured and analysed by the Imagel software. Measurements of abdominal wall muscles PMCT present statistically differences $(P<.05)$ for an increase of perimuscular connective tissue of external oblique (PMCTEO), perimuscular connective tissue of transversus abdominis (PMCTTA) of the left side and an increase of PMCTEO on the right side in favor of the elite group. Rather, the study showed statistically differences $(P<.05)$ for a decrease of perimuscular connective tissue between the internal oblique and transversus abdominis (PMCTIO-TA), and a decrease in PMCT total summation of the left side with elite group in respect to amateur group. This study reported an increase of left PMCTEO, left PMCTTAA, right PMCTEO as well as a decrease of left PMCTIO-TA and in PMCT total summation on the left side.
\end{abstract}

KEYWORDS: connective tissue, oblique abdominis, rectus abdominis, transversus abdominis, ultrasonography, basketball.

\section{INTRODUCTION}

Muscles and perimuscular connective tissue (PMCT) of the abdominal wall develop an important role stabilizing and supporting the spine. ${ }^{1}$ The spine is surrounded in the midline by rectus abdominis (RA), laterally 3 overlapping layers conformed by the external oblique (EO), internal oblique (IO) and trans- versus abdominis (TrAb). ${ }^{2}$ Moreover, these muscles and PMCT have an important role transferring loads from lower limbs to upper limbs and balancing abdominal pressures. ${ }^{3}$ In subjects with lumbopelvic pain (LPP), Whittaker et al. ${ }^{2}$ found a thicker abdominal PMCT. 
Many methods exist to assess the morphology and characteristics of the abdominal wall muscles, including magnetic resonance ${ }^{4}$, eletromiography, ${ }^{5,6}$ and rehabilitative ultrasound imaging (RUSI). These assessment tools have been used to evaluate the thickness, cross sectional area (CSA) and PMCT related to musculoskeletal conditions that may influence the physical therapy approach. ${ }^{7}$ Considering the lower limbs, a recent study found a reduced CSA of the peroneus longus and a negative correlation for the circular perimeter of connective tissue in patients with ankle sprains. ${ }^{8}$ Additionally, Taniguchi et al. ${ }^{9}$ reported a decreased thickness in vastus medialis muscles in subjects with knee osteoarthritis. CSA and thickness of the flexor hallucis brevis and abductor hallucis were reduced in subjects with hallux valgus. ${ }^{10}$ Regarding the upper limb supraspinatus muscle, thickness have been related with subacromial impingement syndrome." Furthermore, CSA of intrinsic hand muscles can be evaluate with RUSI and could be reliable to predict muscle strength in subjects with nerve injury. ${ }^{12}$ With respect to cervical muscles, Javanshir et al. ${ }^{13}$ observed that deep cervical flexor muscles may be evaluated during programs for individuals with neck pain. Temporomandibular joint disorders have showed an altered function of the masseter, temporalis and sternocleidomastoid muscles. ${ }^{14} \mathrm{Ad}-$ ditionally, ultrasonography examinations can be appropriate to assess muscles and PMCT changes in individuals with patology. ${ }^{15}$ Whittacker et al. ${ }^{2}$ found a thicker PMCT and a wider interrecti distance (IRD) in patients with LPP compared with a healthy group. Moreover, multifidus and abdominal wall muscles have been linked with a decreased CSA in patients with LPP. ${ }^{2,16}$

RUSI may consider a non-invasive, relatively affordable and portable tool, which provides information of morphology, and size of muscles and PMCT. ${ }^{2}$ Following Whittacker et al. ${ }^{2}$ criteria, ultrasonography assessments were carried out at rest for muscular tissue, PMCT and IRD of the abdominal wall. Moreover, RUSI evaluation of the trunk and abdominal wall may predict risk of injuries in professional football players. ${ }^{4}$

To date, RUSI comparison of abdominal wall PMCT of elite and amateur players has not been carried out. Therefore, the purpose of this study was to assess and compare with RUSI the PMCT and IRD between elite and amateur basketball players.

\section{METHODS}

Study design

An observational study was developed following the Strengthening the Reporting of Observational Studies in Epidemiology (STROBE) guidelines. ${ }^{17}$

\section{Sample size calculation}

A sample size was calculated using the difference between two independent groups with $\mathrm{G}^{*} \mathrm{Pow}$ er 3.1.9.2 software and based on the IR distance (cm) of a pilot study with 2 groups (mean \pm SD), 10 elite basketball players $(1.35 \pm 1.01 \mathrm{~cm})$ and $10 \mathrm{am}$ ateur basketball players $(0.78 \pm 0.28 \mathrm{~cm})$. Indeed, 1-tailed hypothesis, effect size of $0.99, \alpha$ error probability of 0.05 , power (1- $\beta$ error probability) of 0.90 and allocation ratio (N2/N1) of 1 was carried out for the sample size calculation. Therefore, a total sample size of 20 subjects, 10 for each group, was calculated.

\section{PARTICIPANTS}

A sample of 22 healthy basketball players (age: $21.0 \pm 6.0$ y; height: $1.88 \pm 09.30 \mathrm{~m}$; weight: $85.9 \pm$ $13.5 \mathrm{~kg}$; body mass index, BMI: $22.6 \pm 2.6 \mathrm{~kg} / \mathrm{m}^{2}$ ) was included and divided into two groups: professional elite basketball players from Spanish $1^{\text {st }}$ Division league club ( $\mathrm{n}=11)$ and amateur basketball players from an entertainment Spanish division $(\mathrm{n}=11)$. Inclusion criteria for the present study consisted of individuals aged 18 to 35 years old; male; players with right-handed dominance, right-handed throw, and left-foot jump dominance; the professional group had to meet at least three of the following requirements: a) at least three years as a professional play$\mathrm{er}$; b) playing at least one year in the national team; c) professional players in youth categories; d) having won an international championship with his team or in a national team.

Exclusion criteria were any musculoskeletal disease in the lumbopelvic region ${ }^{2}$, skin disease, hypocapnia, ${ }^{18}$ neurological signs, lower limb pathology (i.e.; fracture, osteoarthritis) and a body mass index (BMI) greater than $31 \mathrm{~kg} / \mathrm{m}^{2}{ }^{2}$ Furthermore, hypocapnia was considered when Nijmegen questionnaire values were higher than $24 .{ }^{19}$

\section{Ethical considerations}

The study was approved by A Coruña University Ethics Committee, Spain, and participants signed the 
informed consent form. The study also adhered to the ethical standards of the Declaration of Helsinki. ${ }^{20}$

\section{Sociodemographic and respiratory distress} data

Before the ultrasonography procedure, age $(y)$, height $(\mathrm{m})$, weight $(\mathrm{kg})$ and BMI $\left(\mathrm{kg} / \mathrm{m}^{2}\right)$ were recorded. Moreover, respiratory distress values were registered with the Nijmegen questionnaire..$^{2,19}$

\section{Ultrasonography of the abdominal wall}

All imaging procedures were carried out by 1 operator (J.A.P), who was a physiotherapist with 3 years of RUSI experience. Following Whittacker et al. ${ }^{2}$ procedure, the operator was not blinded during the ultrasonography examination. A diagnostic ultrasound device (Toshiba Aplio 500 Platinum, Toshiba American Medical Systems; CA, USA) with a 7 to 14-MHz-range linear transducer (18L7 PLT-1204BT type; 40-mm footprint) was used for $B$ mode ultrasound imaging. All images were performed in supine position. For PMCT of the EO, IO and $\operatorname{TrAb}$, the operator was situated in mid-axillary line, using the reference point located between inferior border of subcostal line and iliac crest. PMCT of RA muscle the transducer was placed aligned with the umbilicus; and IRD was evaluated just un- der the umbilicus (Figure 1). ${ }^{2}$ Measurements were collected at right and left sides at the end of expiration with the transducer in the same place. For the statistical analysis, the mean of 3 repeated values for each measure was used. PMCT was defined as the distance between the inside borders of each connective tissue layer. IRD was defined as the distance between the inside borders of both RA. ${ }^{2} \mathrm{Im}$ ageJ software (version 2.0; US National Institutes of Health, Bethesda, Maryland, USA) was utilized for measuring all images offline. ${ }^{21}$

\section{Statistical analysis}

SPSS 22.0 software (IBM SPSS Statistics for Windows; NY: IBM Corp.) was employed for the data analysis. An $\alpha$ error of 0.05 (95\% confidence interval) and desired power of $80 \%$ ( $\beta$ error of 0.2$)$ were used. First, the Shapiro-Wilk test was utilized to assess normality. Second, a descriptive analysis was performed for the total sample together, as well as in both groups separately. Finally, a comparative analysis between both groups was performed. For the parametric data, mean \pm standard deviation (SD) and Student's t-test for independent samples were applied. For the non-parametric data, the median \pm interquartile range (IR) and Mann-Whitney $U$ test were used.
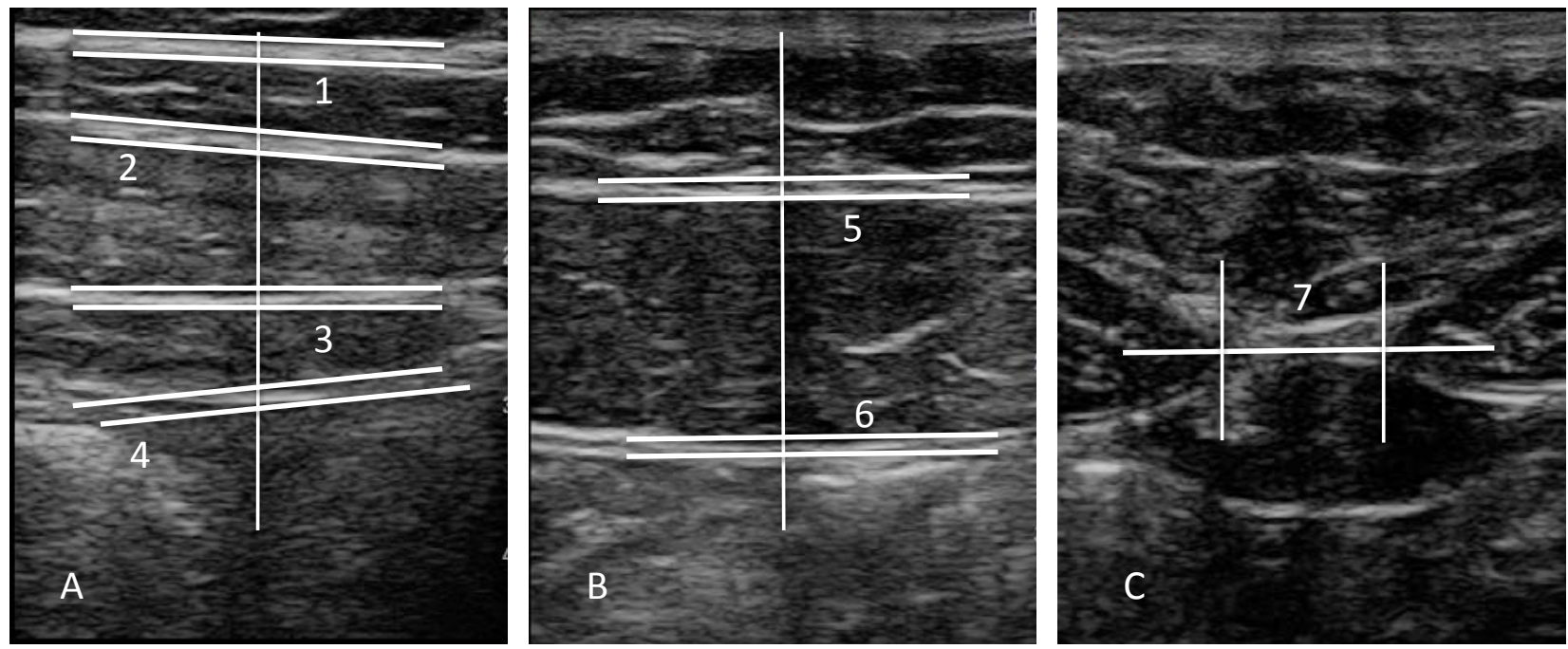

FIGURE 1. DESCRIPTIONS

1. Transducer places during ultrasound evaluation of the abdominal wall.

2. PMCT thickness and IRD measurements of the abdominal wall. 1=PMCTO; $2=P M C T E O-I O ; 3=P M C T I O-T A ; 4=P M C T T A$; 5=PMCTSUPRA; 6=PMCTDEERA; 7=IRD. Abbreviations: IRD, interrecti distance; PMCTEO, perimuscular connective tissue external oblique; PMCTEO-IO, perimuscular connective tissue external oblique- internal oblique; PMCTIO-TA, perimuscular connective tissue internal oblique- transversus abdominis; PMCTTA, perimuscular connective tissue transversus abdominis; PMCTRA, perimuscular connective tissue rectus anterior; PMCTSUPRA, perimuscular connective tissue superficial rectus anterior; PMCTDEERA, perimuscular connective tissue deep rectus anterior. 


\section{RESULTS}

Regarding the Table 1, sociodemographic data did not show statistically significant differences $(P>$.05) for age between both groups. Instead, statistically significant differences $(P<.05)$ were observed in Nijmegen scores in favor of the elite basketball players.

Considering Table 2, measurements of abdominal wall muscles PMCT present statistically differences $(P<.05)$ for an increase of perimuscular connective

TABLE 1. SOCIODEMOGRAPHIC DATA AND RESPIRATORY DISTRESS SCORES OF THE BASKETBALL PLAYERS $\ddagger$

\begin{tabular}{|c|c|c|c|}
\hline Data & Amateur $(n=16)$ & Elite $(n=16)$ & P-value \\
\hline Age, y & $21.0 \pm 3.0 \dagger$ & $23.0 \pm 9.0 \dagger$ & $.748 \neq$ \\
\hline Weight, kg & $79.63 \pm 10.29^{*}$ & $92.18 \pm 13.94$ * & $.026^{\star \star}$ \\
\hline Height, $\mathrm{m}$ & $1.84 \pm 0.07^{*}$ & $1.92 \pm 0.10$ * & $.035^{\star \star}$ \\
\hline $\mathrm{BMI}, \mathrm{kg} / \mathrm{m} 2$ & $21.55 \pm 2.28^{*}$ & $23.72 \pm 2.67^{*}$ & $.054^{\star \star}$ \\
\hline Nijmegen test ${ }^{*}$ & $3.72 \pm 3.13^{*}$ & $12.54 \pm 3.77^{*}$ & $<.001^{* *}$ \\
\hline
\end{tabular}

tissue of external oblique (PMCTEO), perimuscular connective tissue of the transversus abdominis (PMCTTA) of the left side and an increase of PMCTEO on the right side in favor of elite group. Rather, the study showed statistically differences $(P<.05)$ for a decrease of perimuscular connective tissue between the internal oblique and transversus abdominis (PMCTIO-TA), and a decrease in PMCT total summation of the left side with elite group compared to amateur group.

\section{DISCUSSION}

To date, this new study may be considered as the first study to make a comparison of the abdominal wall PMCT between elite and amateur basketball players. To our knowledge, the only study of RUSI examination of PMCT abdominal wall muscles at rest was carried out in subjects with and without LPP. ${ }^{2}$ Langevin and Sherman ${ }^{22}$ have hypothesized that PMCT plays an important role in subjects with LPP. Additionally, greater thickness (22\%) of PMCT was found in patients with LPP. ${ }^{23} \mathrm{~A}$ dominant patterns like left-foot jump dominance may predispose an extra mechanical stress as well

TABLE 2. ULTRASOUND IMAGING OF THE INTERRECTI DISTANCE AND PERIMUSCULAR CONNECTIVE TISSUE.

\begin{tabular}{|c|c|c|c|}
\hline Measurement & Amateur $(n=16) \dagger$ & Elite $(n=16) \dagger$ & P-value \\
\hline \multicolumn{4}{|l|}{ Distance $(\mathrm{cm})$} \\
\hline IRD & $1.04 \pm 0.51(0.64-1.96)^{\dagger}$ & $1.28 \pm 0.69(0.54-3.64)^{\dagger}$ & $0.001^{\ddagger}$ \\
\hline \multicolumn{4}{|l|}{ Thickness (cm) } \\
\hline Right PMCTEO & $2.00 \pm 4.00(0.01-11.00) \dagger$ & $0.45 \pm 0.18(1.15-0.81)^{\dagger}$ & $0.001^{\ddagger}$ \\
\hline Right PMCTEO-IO & $0.11 \pm 0.05(0.07-0.33)^{\dagger}$ & $0.10 \pm 0.07(0.19-0.11)^{\dagger}$ & $0.847^{\ddagger}$ \\
\hline Right PMCTIO-TA & $0.12 \pm 0.04(0.07-0.24)^{*}$ & $0.04 \pm 0.04(0.09-0.25)^{*}$ & $0.371^{\prime \prime}$ \\
\hline Right PMCTTA & $0.09 \pm 0.09(0.06-0.29)^{\dagger}$ & $0.13 \pm 0.04(0.09-0.22)^{\dagger}$ & $0.193^{\ddagger}$ \\
\hline Right PMCTRA & $0.16 \pm 0.03(0.11-0.24)^{*}$ & $0.14 \pm 0.02(0.11-0.18)^{\circ}$ & $0.334^{\prime \prime}$ \\
\hline Right PMCTSUPRA & $0.09 \pm 0.02(0.06-0.14)^{*}$ & $0.08 \pm 0.02(0.05-0.12)^{*}$ & $0.446^{\prime \prime}$ \\
\hline Right PMCTDEERA & $0.06 \pm 0.03(0.04-0.10)^{\dagger}$ & $0.06 \pm 0.01(0.04-0.07)^{\dagger}$ & $0.898^{\ddagger}$ \\
\hline Total Right PMCT & $0.09 \pm 0.04(0.06-0.22)^{\dagger}$ & $0.11 \pm 0.03(0.08-0.17)^{\dagger}$ & $0.438^{\ddagger}$ \\
\hline Left PMCTEO & $0.11 \pm 0.05(0.06-0.23) \dagger$ & $0.47 \pm 0.12(0.36-0.65)^{\dagger}$ & $0.001^{\ddagger}$ \\
\hline Left PMCTEO-IO & $0.11 \pm 0.29(0.07-0.17)$ & $0.11 \pm 0.28(0.08-0.16)^{*}$ & $0.520 "$ \\
\hline Left PMCTIO-TA & $0.90 \pm 0.01(0.06-0.13)^{\dagger}$ & $0.13 \pm 0.06(0.10-0.28)^{\dagger}$ & $0.001^{\ddagger}$ \\
\hline Left PMCTTA & $0.09 \pm 0.03(0.08-0.15)^{\dagger}$ & $0.13 \pm 0.03(0.10-0.21)^{\dagger}$ & $0.001^{\ddagger}$ \\
\hline Left PMCTRA & $0.16 \pm 0.05(0.12-0.28)^{*}$ & $0.14 \pm 0.04(0.08-0.20)^{\circ}$ & $0.256^{\prime \prime}$ \\
\hline Left PMCTSUPRA & $0.09 \pm 0.07(0.20-0.14)^{\dagger}$ & $0.08 \pm 0.05(0.05-0.13)^{\dagger}$ & $0.401^{\ddagger}$ \\
\hline Left PMCTDEERA & $0.06 \pm 0.02(0.04-0.12)^{*}$ & $0.05 \pm 0.01(0.03-0.09)^{*}$ & $0.369^{\prime \prime}$ \\
\hline Total Left PMCT & $0.41 \pm 0.15(0.31-0.61)^{\dagger}$ & $0.10 \pm 0.03(0.08-0.14)^{\dagger}$ & $0.001^{\ddagger}$ \\
\hline
\end{tabular}

Abbreviations: IRD, interrecti distance; PMCTEO, perimuscular connective tissue external oblique; PMCTEO-IO, perimuscular connective tissue external oblique- internal oblique; PMCTIO-TA, perimuscular connective tissue internal oblique- transversus abdominis; PMCTTA, perimuscular connective tissue transversus abdominis; PMCTRA, perimuscular
connective tissue rectus anterior; PMCTSUPRA, perimuscular connective tissue superficial rectus anterior; PMCTDEERA, perimuscular connective tissue deep rectus anterior. ${ }^{\star}$ Mean \pm standard deviation (SD) (minimum-maximum) was applied. ${ }^{*}$ Student's $t$-test for independent samples was performed. $\dagger$ Median \pm interquartile range (IR) (minimum-maximum) was used. $\ddagger$ Mann-Whitney $U$ test was utilized. 
as physiological changes in this tissues. ${ }^{22}$ Fibrosis of the connective tissues are known to occurs as a result of repeated trauma and inflammation. ${ }^{24}$, ${ }^{25}$ Based on these findings, it is possible to hypothesize the relation between too many training sessions, high intensity, high loads, abnormal movement patters and adaptive connective tissue changes. In addition, right-handed dominance, right-handed throw, and left-foot jump dominance may be related with the abdominal wall connective tissue morphology. Further studies may be necessary in order to correlate these player's characteristics with the connective tissue morphology.

Regarding the studies performed by Hides et al. ${ }^{26}$ and Leung et al. ${ }^{27}$, a motor control RUSI examination of the abdominal wall muscles could be considered as an important index to predict the risk of injuries in soccer players. Likewise, studies developed by Hides et al. ${ }^{28}$ showed that a motor control program improves the ability to drawn-in abdominal wall in soccer players and normalize excessive tension of abdominal muscles in response to a low load task. ${ }^{29}$

Our sample was composed of healthy subjects and showed a higher IRD for the elite group contrary to LPP subjects. ${ }^{2}$ Nijmegen test registered fourfold higher score of respiratory distress in favor elite basketball players. Moreover, the scores are coinciding with the Nijmegen values between patients with and without LPP. ${ }^{2}$

\section{LIMITATIONS AND FUTURES STUDIES}

Several limitations should be contemplated in this study. First, the sample was composed of healthy players, so it would be interesting in future investigations to study players with pathology, such as LPP. ${ }^{2}$ Second, muscle contraction changes were not studied and the ultrasound exploration during abdominal hollowing, functional tasks, dynamic movements, straight leg raise test or Valsalva manoeuvre might be interesting. 15, 27,30

At last, ultrasonography M-Mode and power Doppler mode may be useful for the study of PMCT characteristics providing functional thickness examinations and a direct visualization of inflammation within the layers and tissues. ${ }^{31,32}$

Further research is recommended to determine characteristics of the abdominal wall structures like muscle and PMCT in elite athletes different from basketball. Moreover, it would be very interesting to examine other sports and populations with RUSI.

\section{CONCLUSIONS}

This study reported an increase of left PMCTEO, left PMCTTAA, right PMCTEO, as well as a decrease of left PMCTIO-TA and in PMCT total summation on the left side.

\section{Conflicts of Interest and Source of Funding}

There are no conflicts of interest or Source of Funding.

\section{RESUMO}

O objetivo deste estudo foi avaliar e comparar com ultrassonografia de reabilitação (IUR) o tecido conjuntivo perimuscular da parede abdominal (PMPA) e interrecti distância (IRD) entre elite e jogadores de basquete amadores. Uma amostra de 22 jogadores de basquete saudáveis foi incluída e dividida em dois grupos: jogadores de basquete de elite da 1a divisão espanhola ( $n=11$ ) e jogadores de basquete amadores de uma divisão de entretenimento espanhol $(n=11)$. As imagens de ultrassom do oblíquo externo (OE), oblíquo interno (OI), transverso abdominal (TrAb), recto anterior (RA) e IRD PMPA foram medidas e analisadas pelo software Image). Medições dos músculos da parede abdominal O PMPA apresentam diferenças estatisticamente $(P<0,05)$ para o aumento do tecido conjuntivo perimuscular de oblíquo externo (PMOE), tecido conjuntivo perimuscular de transverso abdominal (PMTA) do lado esquerdo e aumento do PMOE do lado direito a favor do grupo de elite. Em vez disso, o estudo mostrou diferenças estatisticamente $(P<0,05)$ para uma diminuição do tecido conjuntivo perimuscular entre o oblíquo interno e transverso abdominário (PMOI-TA) e uma diminuição no somatório total de PMTA do lado esquerdo do grupo de elite em relação ao amador grupo. Este estudo relatou um aumento do PMTOE esquerdo, PMTA esquerdo, PMCTOE direito, bem como uma diminuição do PMCTOI-TA esquerdo e no somatório total do PMTA no lado esquerdo.

PALAVRAS-CHAVE: Tecido conjuntivo. Abdome oblíquo. Reto abdominal. Abdominal transverso. Ultrassonografia.

\section{REFERENCES}

1. Reeves NP, Everding VQ, Cholewicki ], Morrisette DC. The effects of trunk stiffness on postural control during unstable seated balance. Exp Brain Res. 2006;174:694-700.

2. Whittaker JL, Warner MB, Stokes M. Comparison of the sonographic features of the abdominal wall muscles and connective tissues in individuals with and without lumbopelvic pain. J Orthop Phys Ther. 2013;49:11-19.
3. Brown SH, Ward SR, Cook MS, Lieber RL. Architectural analysis of human abdominal wall muscles: implications for mechanical function. Spine. 2011;36: 355-62.

4. Hides J, Wilson S, Stanton W, McMahon S, Keto H, McMahon K, Bryant $M$, Richardson C. An MRI investigation into the function of the transversus abdominis muscle during "Drawing-In" of the abdominal wall. Spine. 2006;31:E175-E178. 
5. Ferreira PH, Ferreira ML, Nascimento DP, Pinto RZ, Franco MR, Hodges PW. Discriminative and reliability analyses of ultrasound measurement of abdominal muscles recruitment. Man Ther. 2011;16:463-469.

6. Hodges PW, Pengel LH, Herbert RD, Gandevia SC. Measuremente of muscle contraction with ultrasound imaging. Muscle Nerve. 2003;27:682-692.

7. Potter $\mathrm{CL}$, Cairns MC, Stokes M. Use of ultrasound imaging by physiotherapists: a pilot study to survey use, skills and training. Man Ther. 2012;17:39-46.

8. Lobo CC, Morales CR, Sanz DR, Corbalán IS, Marín AG, López DL. Ultrasonography comparison of peroneus muscle cross-sectional area in subjects with or without lateral ankle sprains. J Manipulative Physiol Ther. 2016;39(9):635-644.

9. Taniguchi M, Fukumoto $Y$, Kobayashi $M$, et al. Quantity and quality of the lower exremity muscles in women with knee osteoarthritis. Ultrasound Med Biol. 2015;41(10):2567-2574.

10. Lobo CC, Marín AG, Sanz DR, López DL, López PP, Morales CR, Corbalán IS. Ultrasound evaluation of intrinsic plantar muscles and fascia in hallux valgus: A case control study. Medicine. 2016;95(45):e5243.

11. Blume C, Wang SS. Comparison of changes in supraspinatus muscle thickness in persons with subacromial impingement syndrome and asymptomatic adults. Physioter Theory Pract. 2014:30(8):544-551.

12. Mohsen B, Nijhuis TH, Hunderpool CA, Janssen WG, Selles RW, Coert $\mathrm{HH}$. Ultrasonographic quantification of intrinsic hand muscle cross sectional area: reliability and validity for predicting muscle streght. Arch Phys Med Rehabil. 2015;96(5):845-853.

13. Javanshir K, Amiri M, Bandpei MA, Penas CF, Rezasoltani A. The effect of different exercise programs on cervical flexor muscles dimensions in patients with chronic neck pain. J Back Musculoskeletal Rehabil. 2015;28(4):833-840.

14. Strini PJ, Barbosa T, Gaviao MB. Assessment of thickness and function of masticatory and cervical muscles in adults with and without temporomandibular disorders. Arch Oral Biol. 2013;58:1100-1108.

15. Teyhen DS, Gill NW, Whittaker JL, Henry SM, Hides JA, Hodges P. Rehabilitative ultrasound imaging of the abdominall muscles. J Orthop Phys Ther. 2007;37:450-66.

16. Kiesel KB, Underwood FB, Mattacola CG, Nitz A|, Malone TR. A comparison of select trunk muscle thickness change between subjects with low back pain classified in the treatment based classification system and asymptomatic controls. J Orthop Sports Phys Ther. 2007;37(10):596-607.

17. White RG, Hakim AJ, Salganik MJ, et al. Strengthening the reporting of observational studies in epidemiology for respondent driven sampling studies: "STROBE-RDS" statement. J Clin Epidemiol. 2015;68(12):1463-1471.

18. Whittacker JL. Ultrasound imaging of the lateral abdominal wall muscles in individuals with lumbopelvic pain and signs concurrent hypocapnia. Man Ther. 2008;13:404-4010.

19. Van Dixhoorn J, Duivenvoorden HJ. Efficacy of Nijmegen Questionnaire in recognition of the hyperventilation syndrome. J Psychosom Res. 1985;29:199-206.

20. Holt GR. Declaration of Helsinki. The world document of conscience and responsability. South Med J. 2014;107:407-407.

21. Schneider CA, Rasband WS, Eliceiri KW. NIH Image to Image): 25 years of image analysis. Nat Methods. 2012;9:671-5.

22. Langevin HM, Sherman KJ. Pathophysiological model for chronic low back pain integrating connective tissue and nervous system mechanisms. Med Hypotheses. 2007;68:74-80.

23. Lengevin HM, Stevens-Tuttle D, Fox JR, et al. Ultrasound evidence of altered lumbar connective tissue structure in human subjects with chronic low back pain. BMC Musculoskelet Disord. 2009;10:151.

24. Ettema AM, Amadio PC, Zhao C, Wold LE, An KN.A histological and immunohistochemical study of the subsynovial connective tissue in idiopathic carpal tunnel syndrome. J Bone Joint Surg Am. 2004;86-A:14581466.

25. Perry SM, MCIIlhenny SE, Hoffman MC, Soslowsky LJ. Inflammatory and angiogenic $m R N A$ levels are altered in a supraspinatus tendon overuse animal model. J Shoulder Elbow Surg. 2005. 14:79S-83S.

26. Hides JA, Stanton WR, Mendis MD, Franettovich MM, Sexton MJ. Small multifidus muscle size predicts football injuries. Orthop J Sports Med. 2014;2(6):232596711453758.

27. Leung FT, Mendis MD, Stanton WR, Hides IA. The relationship between the piriformis muscle, low back pain, lower limb injuries and control motor training among elite football players. J Sci Med Sport. 2015;18:407-411.

28. Hides JA, Stanton WR, Mendis MD, Gildea J, Sexton MJ. Effect of motro control training on muscle size and football games missed from injury. Med Sci Sports Exerc. 2012;44(6):1141-9.

29. Hides JA, Endicott T, Mendis MA, Stanton WR. The effect of motor control training on abdominal muscle contraction during stimulated weight bearing elite cricketers. Phys Ther Sport. 2016;20:26-31.

30. Ferreira PH, Ferreira ML, Hodges WR. Changes in recruitment of the abdominal muscles in people with low back pain: ultrasound measurement of muscle activity. Spine. 2004;29:2560-6.

31. Merot $\mathrm{O}$, Le Goff $\mathrm{B}$. Ultrasonography in chronic inflammatory rheumatic and connective tissue disorders. Rev Med Interne. 2014;35(8):531-9.

32. Costa LO, Maher CG, Latimer J, Smeets RJ. Reproducibility of rehabilitative ultrasound imaging for the measurement of abdominal muscle activity: a systematic review. Phys Ther. 2009;89(8):756-69. 